\title{
Kebijakan industrial(isasi) dan kontinyuitas konflik industrial pasca krisis ekonomi 1997/1998
}

\author{
Industrial policy continuity of industrial conflict post 1997/1998 crisis
}

\author{
Sigit Rochadi \\ Ilmu Komunikasi, Universitas Nasional, Jakarta, Indonesia \\ Sawo Manila Pejaten PS Minggu Jakarta 12520, Indonesia. Telepon: (021) 7806700. \\ E-mail: sigitrochadi@yahoo.com
}

\begin{abstract}
This article examines the relations between industrial policy and industrial conflict in Indonesia pos the 1997 economic crisis. The method uses is descriptive analysis. This research founded that the country's industrial policy was influenced by strong nationalism sentiment of both indigenous and industrialism. This study shows that a prolonged conflict was also influenced by a narrow industry policy. The data was analyzed by descriptive method using critical interpretation; secondary data analysis was conducted by comparing years, business scope, and influencing parties (government, businessman, and labour). The policy did not provide opportunity to strengthen labour, therefore, the issues they echoed was not about technological development or job opportunities, but concerned more about wages or overtime work pay. A successful industrial structural development was not only useful to strengthen national economy, the more important fact is the empowerment of labout through good leadership and democracy.
\end{abstract}

Keywords: industrial policies, sentiment nationalis, industrial conflict

\begin{abstract}
Abstrak
Artikel ini membahas hubungan kebijakan industri/industralisasi dengan masifnya konflik industrial pasca krisis ekonomi 1997. Metode penelitian yang digunakan dalam penelitian ini adalah metode deskriptif. Metode deskriptif adalah suatu metode dalam meneliti status sekelompok manusia, suatu objek, suatu kumpulan kondisi, suatu sistem pemikiran atau suatu peristiwa pada masa sekarang. Hasil studi ini menunjukkan bahwa terus berlangsungnya konflik industrial juga disumbang oleh kebijakan industri yang cenderung meluas dan bukan pendalaman. Analisis data dilakukan secara gabungan, yaitu deskripsi dengan interpretasi kritis dan analisis data sekunder dengan membandingkan antar tahun, antar lapangan usaha, antar kelompok (pemerintah, pengusaha dan buruh). Kebijakan demikian tidak memberi peluang penguatan pekerja, sehingga isu-isu yang diusung oleh pekerja bukan perkembangan teknologi dan isu lapangan pekerjaan, melainkan lebih banyak mempersoalkan upah, tunjangan hari raya dan lembur. Pembangunan struktur industri yang berhasil dari industri hulu-antarahilir, bukan hanya bermanfaat bagi penguatan ekonomi nasional, fakta yang tidak kalah penting adalah penguatan para pekerja melalui kepemimpinan dan inovasi.
\end{abstract}

Kata kunci: kebijakan industri, nasionalisme ekonomi, konflik industrial

\section{Pendahuluan}

Kajian mengenai hubungan industrialisasi dengan masifnya konflik industrial pada umumnya terfokus pada terbentuknya kekuatan buruh, sebagai konsekuensi dianutnya strategi industrialisasi berorientasi ekspor (IOE). Riset Hadiz (1997) menunjukkan perubahan strategi industrialisasi berorientasi impor (ISI) ke strategi IOE, dimana negara harus mendisiplinkan pekerja untuk menjamin masuknya modal asing, produktivitas dan ekspor non-migas. Pembentukan buruh sebagai angkatan kerja murah berlangsung di zona-zona industri baru yang tumbuh sejak pertengahan tahun 1980-an. Gelombang protes buruh yang terus berlangsung sebagai akibat pelanggaran terhadap hak-hak buruh yang dilakukan untuk membiayai birokrasi dalam mendisplinkan buruh. Riset Alexander Irwan (1999) menjelaskan kuatnya patronase bisnis dan kekuasaan selama Orde Baru dengan mengisolasi gerakan sosial. Industrialisasi yang berlangsung di negeri ini tetap berada di anak tangga terbawah dalam 
struktur industri karena patronase bisnis menggerogoti perekonomian. Apa yang berlangsung di Indonesia tersebut, bertolak belakang dengan pengalaman Korea Selatan dan Thailand. Meskipun di kedua negara ini juga pernah berlangsung patronase bisnis, sebagaimana dikemukakan oleh Budiman (1994), Robert Wade (1992) dan Richard Doner (1998), tetapi berhasil mengikis patronase dan menciptakan efisiensi produksi, kemudian mengandalkan keunggulan kompetitif.

Berbeda dengan studi-studi yang sudah disebutkan sebelumnya, studi ini berasal dari hipotesis bahwa masifnya konflik industrial bukan semata-mata kekerasan yang dilakukan oleh negara, tetapi juga kebijakan industrial yang kurang cepat melakukan pendalaman, sehingga tidak memberi peluang penguatan pekerja. Sebagai akibatnya terus berlangsung konflik industrial, dengan isu-isu yang sama, seperti upah dan tunjangan hari raya. Pembangunan struktur industri yang berhasil dari industri huluantara-hilir, bukan hanya bermanfaat bagi penguatan ekonomi nasional, fakta yang tidak kalah penting adalah penguatan para pekerja melalui kepemimpinan dan inovasi.Pekerja yang kuat (terutama yang tergabung dalam gerakan) dalam struktur industri yang kuat, mengarahkan isu-isu protes yang lebih bermuatan sektor pekerjaan dibanding isu lainnya. Sebaliknya dalam struktur industri yang lemah, terutama industri hilir yang berlebihan dengan fungsi sebagai perakit, sumber daya pekerja tidak berkembang dan terus menerus mempersoalkan upah. Kondisi demikian juga mudah terseret arus ke dalam gerakan politik, baik untuk mendukung partai tertentu atau untuk mendukung calon dalam pemilihan kepala daerah.

\section{Metode Penelitian}

Metode yang digunakan dalam penelitian ini adalah deskriptif. Menurut Moh. Nasir (2001:63) metode deskriptif adalah suatu metode dalam meneliti status sekelompok manusia, suatu objek, suatu kumpulan kondisi, suatu sistem pemikiran atau suatu peristiwa pada masa sekarang. Vrendenbregt (1980:15) menyebut deskriptif analisis, karena peneliti bukan hanya mendeskripsikan apa yang terjadi, tetapi juga menjelaskan mengapa gejala tersebut terjadi. Dalam penelitian ini, suatu kumpulan kondisi tersebut adalah kebijakan industri dan kontinyuitas konflik industrial. Oleh karena deskripsi atas gejala tersebut memiliki cakupan yang panjang, maka penelitian ini lazim disebut deskriptif berkesinambungan (continuity descriptive) (Nasir 2001:65). Metode ini dapat mengajukan hipotesis untuk memandu pengumpulan data dan analisis data, tetapi tidak diuji secara statistik.

Data yang yang dianalisis berupa data sekunder utamanya hasil survei dan sensus Badan Pusat Statistik, publikasi Bank Dunia, IMF, WTO dan kementrian perindustrian, selain itu dirujuk sejumlah kebijakan industri yang secara langsung membentuk hubungan industrial utamanya konflik industrial, sedangkan data tentang respon buruh, pengusaha dan pemerintah diperoleh dari berbagai sumber khususnya majalah, surat kabar dan tabloid. Memperhatikan sumber data, Majchrcak (1984:18) menamai metode ini secondary analysis. Analisis data dilakukan secara gabungan, yaitu deskripsi dengan interpretasi kritis dan analisis data sekunder dengan membandingkan antar tahun, antar lapangan usaha, antar kelompok (pemerintah, pengusaha dan buruh) (Nugroho 2013:120). Apabila diposisikan dalam pendekatan kualitatif, analisis data seperti itu oleh Neuman (2013:573) termasuk dalam analisis ilustratif dimana peneliti menerapkan teori untuk situasi historis dan situasi sekarang. Teori yang telah ada merupakan kotak kosong yang dapat diisi dengan bukti empiris baik berupa data kuantitatif maupun kualitatif. Layaknya tubuh, teori merupakan kerangka yang memerlukan daging dan darah untuk bertahan hidup berupa data.

\section{Hasil dan Pembahasan}

\section{Kebijakan industri(alisasi)}

Negara-negara yang belakangan melakukan industrialisasi (late industrialization), bukan hanya cenderung otoriter seperti dinyatakan oleh Gerschenkron (Selwyn 2011) untuk mengawal modal dan mendisiplinkan buruh, tetapi juga harus mencari modelnya sendiri. Model yang paling lazim adalah mendayagunakan dua kekuatan penting, yaitu negara dan buruh (Austin 2010). Indonesia dan 
sejumlah negara Asia lainnya dalam mengawali industrialisasi, tidak memperlihatkan kerjasama negara dan buruh, sebaliknya justru negara mengendalikan buruh dengan berbagai cara (Kim 2005, Rasiah dan Hing 2009). Meskipun demikian, kebanyakan para elite di negara-negara itu terus berselisih antara strategi substitusi impor atau strategi berorientasi ekspor.

Para pendiri bangsa ini lebih cenderung dengan strategi substitusi impor (import substitution industry) sebagai perwujudan nasionalisme. Sebagaimana dirangkum oleh Feith dan Castle (1988), masyarakat Indonesia yang maju menurut pandangan para pemimpin pergerakan adalah masyarakat industri, menguasai dan memanfaatkan teknologi untuk kesejahteraan bangsa. Oleh sebab itu, meskipun kabinet terus menerus mengalami perubahan selama pemerintahan Orde Lama, tetapi program untuk melakukan industrialisasi terus mengemuka. Anggapan bahwa industri yang kuat yang tumbuh dari sektor pertanian ke industri berat adalah tahapan modernisasi ekonomi Indonesia, tetapi Soekarno gagal dalam memimpin pembangunan ekonomi akibat kebencian yang berlebihan terhadap modal asing seraya mencari perpaduan terbaik sosialisme dan nasionalisme yang tidak pernah dia temukan.

Kegagalan Soekarno dan pembunuhan massal tahun 1966-1967, menjadi titik balik kebijakan industri. Pemerintah Orde Baru pengganti Soekarno memperoleh momentum penting dalam merumuskan dan mengimplementasikan kebijakan industri karena para perintang relatif kecil. Dominannya militer dalam pemerintahan dibantu para ahli ekonomi, menempatkan pemerintah sebagai satu-satunya kekuatan sosial dalam negara. Strategi industrialisasi yang dikendalikan negara menjadi pilihan yang dicirikan oleh program substitusi impor. Strategi semacam ini melakukan proteksi yang tinggi terhadap industri dalam negeri, pengawasan-pengawasan langsung terhadap impor dan investasi. Diskriminasi dalam tarif, kuota, lisensi investasi, subsidi pajak dan kredit juga merupakan karakteristik penting strategi industri substitusi impor (ISI) (Tambunan 2001:48). Langkah seperti itu perlu diambil, bukan hanya alasan ekonomi, seperti pasar dalam negeri yang potensial dan kesempatan tenaga kerja Indonesia menguasai ketrampilan teknis dan manajerial (Arif dan Hill 1985:17, Wie 1994:29), mengurangi ketergantungan terhadap impor yang berarti juga mengurangi defisit saldo neraca perdagangan dan menghemat cadangan devisa (Tambunan 2001:48), alasan yang tidak kalah penting adalah kuatnya ideologi nasionalisme para pemimpin Indonesia sepanjang masa. Ideologi ini berakar pada perjuangan kemerdekaan dan terus dipelihara melalui berbagai gerakan dan partai politik. Momentum yang tidak kalah penting adalah keuntungan dari ekspor minyak yang memberikan pemasukkan keuangan negara dan memperluas peran pemerintah. Begitu besarnya pemasukan negara pada tahun 1970-an, sehingga tugas Menteri Keuangan lebih pada bagaimana membelanjakan uang negara (Sjahrir 1993:50).

Fokus kebijakan industri pada tahun 1970-an adalah industri berat, seperti baja, pupuk dan semen. Berbeda dengan kasus di Asia Timur, Malaysia dan Muangthai, dimana kebijakan negara yang pada tahap awal menekankan ISI, para penyusun kebijakan industri pemerintah Orde Baru memperlihatkan bahwa negara mempunyai kepentingan sendiri yang relatif bebas dari jangkauan kelompok-kelompok. Berkat keuangan negara yang melimpah, kemampuan menciptakan depolitisasi massa dan relatif homogennya elit penentu kebijakan, pemerintah Orde Baru memiliki otonomi yang demikian besar. Situasi ini dijelaskan dengan baik oleh teori politik birokrasi dari Jackson (1978), teori patrimonialisme dari Crouch (1979), maupun teori state qua state dari Anderson (1983). Negara secara langsung memperlihatkan ideologi industrialisasi yang hasilnya dapat dilihat dari pertumbuhan pesat sektor industri selama 1970-1982. Pada periode itu sektor manufaktur meningkat pesat rata-rata sebesar 14 persen. Jika tahun 1967 sektor sekunder hanya menyumbang 10 persen terhadap PDB, tahun 1982 telah mencapai 18,3 persen. Saham industri logam dan mesin dalam nilai tambah sektor manufaktur melonjak dua kali dari 7,0 persen tahun 1970 menjadi 14,1 persen tahun 1985, sedang pertumbuhan industri logam pada periode yang sama rata-rata 19,2 persen per tahun (BPS Statistik Industri 1986).

Kemajuan pesat sektor industri ini tidak bisa dipisahkan dari tiga variabel penting kebijakan industri, yaitu ideologi industrialisasi, proteksi negara, dan peningkatan pendapatan negara yang luar biasa dari minyak bumi. Berbeda dengan departemen ekonomi lain, departemen perindustrian senantiasa 
dipimpin oleh para penganut ideologi industrialisme (Chalmers 1996:96). Pada awal Orde Baru departemen ini lebih memperlihatkan nasionalisme ekonomi ke dalam dan secara ideologis berhadapan dengan modal asing. Kasus Malari 1974 menunjukkan sentimen nasionalisme ekonomi, yang kemudian bergeser menjadi sentimen anti Cina, sehingga lebih mewakili pribumisme. Mulai Pelita III, kebijakan industri dapat disebut sosialisme hulu dan kapitalisme hilir (Wie 1994:31), lebih menggambarkan bangkitnya ideologi industrialisme. Dalam ideologi ini, nasionalisme tidak seluruhnya berorientasi ke dalam, yang hanya akan melahirkan konflik antar golongan, melainkan juga diorientasikan ke luar, seperti dapat disimak dari pemikiran Soehoed (1988) ideologi ini berusaha memanfaatkan ekonomi nasional yang diperoleh dari pendapatan minyak bumi untuk melakukan negosiasi dengan modal asing.

Menguatnya ideologi industrialisme sejak pertengahan tahun 1980-an, minimal didorong oleh tiga faktor penting, yaitu merosotnya pendapatan negara dari minyak bumi, proses internasionalisasi ekonomi, dan persaingan antar perusahaan asing dalam menembus pasar domestik. Kelangkaan sumber daya finansial pemerintah sejak tahun 1983 yang disebabkan oleh merosotnya harga minyak di pasar internasional, telah membawa kelangkaan devisa. Pemerintah membanting setir dengan menjadwal ulang proyek-proyek pembangunan (rata-rata industri hulu dan industri berat) dan menarik modal asing. Dilakukanlah devaluasi nilai tukar dan deregulasi perbankan guna memfasilitasi bekerjanya industrialisme. Pajak secara besar-besaran dikampanyekan sebagai bukti warga negara yang baik. "Orang bijak taat pajak" merupakan slogan yang menandai revolusi dari atas, suatu perubahan cepat yang digerakkan oleh pemerintah dibidang perpajakan ini. Sebelum tahun 1982, proporsi pajak terhadap PDB hanya 6 persen atau hanya 3,8 trilyun. Angka tersebut telah bergeser menjadi 14,8 persen PDB sepuluh tahun kemudian. Kebijakan paling konkrit yang menandai merosotnya kekuatan pribumisme adalah kebijakan pengurangan dan penghapusan tarif dari $0-225$ persen tinggal 0-60 persen.

Proses internasionalisasi ekonomi menjadi wacana publik awal tahun 1980-an. Pasca pemulihan hubungan diplomatik dengan RRC tahun 1979, KADIN mengeluarkan pernyataan pentingnya pengusaha Indonesia melakukan investasi di China. Diyakini hubungan pengusaha nasional dengan internasional melalui MNC (Multi National Corporation) dapat meningkatkan perekonomian suatu negara. Integrasi ekonomi ke pasar internasional merupakan keharusan dan bukan pilihan, sebuah tesis yang diucapkan kembali oleh Presiden Soeharto "suka atau tidak suka dan siap atau tidak siap, Indonesia harus menyatukan diri" tahun 1994 ketika Indonesia mempersiapkan diri sebagai tuan rumah Konferensi APEC. Inpres No. 5 Tahun 1984, Paket Mei 1990 dan Paket Juli 1992, menandai perekonomian Indonesia yang semakin liberal. Deregulasi terakhir khususnya menyentuh sektor penanaman modal dan industri besi baja (boleh impor besi dengan pengenaan tarif), semakin menarik investor asing. Salah satu kelebihan Indonesia adalah tersedianya tenaga kerja yang melimpah dan kendali keamanan, serta ketertiban yang kuat. Kondisi ini meningkatkan persaingan perusahaan asing untuk menembus pasar Indonesia yang sangat besar. Di sinilah kekuatan pendukung industrialisme meningkat dan turut menyuburkan birokrasi rente.

Sampai berakhirnya Pelita IV, homogenitas ideologi dikalangan elit masih cukup kuat. Para penentang kebijakan industrialisme kehilangan momentum, terlebih-lebih wacana globalisasi yang dipicu oleh ambruknya Uni Soviet dan Jerman Timur semakin menguat. Peristiwa ini diyakini oleh para penganut demokrasi liberal dan ekonomi pasar sebagai kemenangan tombak kembar tersebut dalam persaingan ideologi global (Fukuyama 1992). Namun, di akar rumput terus muncul protes dari para buruh menuntut para pengusaha membayar upah sesuai KUM (ketentuan upah minimum). Pada tahun 1990 berlangsung 61 kali protes buruh, tahun 1992 ada 251 kali dan tahun 1994 mencapai 270 kali. Pada awal tahun 1990-an tiada hari tanpa protes buruh. Pendekatan keamanan dari aparat semakin ketat yang menewaskan beberapa buruh. Peristiwa paling menonjol adalah pembunuhan seorang buruh perempuan (Marsinah) di Sidoarjo oleh aparat militer tahun 1992. Kejadian ini mendorong konsolidasi para aktivis gerakan sosial, sehingga melahirkan beberapa gerakan seperti Serikat Buruh Merdeka Setia Kawan (SBMS) dan Serikat Buruh Sejahtera Indonesia (SBSI) (Rochadi 1996).

Masifnya konflik industrial mendorong dilakukannya penyelidikan oleh Komnas HAM dan menyimpulkan terjadinya pelanggaran HAM yang serius oleh militer. Temuan ini menyudutkan 
ABRI, ditambah simpulan utusan PBB dalam kasus Santa Cruz di Timor Timor, menyebabkan terjadinya perpecahan di kalangan militer. Presiden Soeharto mulai mengurangi ketergantungannya kepada militer dan membangun kekuatan penyangga baru bernama ICMI. Para pendukung pribumisme bangkit kembali, meskipun sedikit bernuansa primordial. Industrialisme yang antara lain melahirkan para konglomerat, dituduh terlalu memanjakan investor asing, pemodal kuat, menyuburkan birokrasi rente, mematikan industri kecil dalam negeri yang dikuasai tokoh-tokoh Islam dan menguntungkan pengusaha keturunan China. Menguatnya posisi B.J. Habibie dalam politik, yang antara lain memimpin tujuh industri strategis, Ketua ICMI, Menristek/Ketua BPPT dan Ketua Harian Dewan Pembina Golkar, memunculkan wacana Habibinomics yang kental bermuatan pribumisme kontras dengan Wijoyonomics yang lebih bermuatan industrialisme, tetapi momentum untuk melakukan industrialisasi dibawah bimbingan negara tidak seluas sebelumnya. Selain keuangan negara yang lemah dan perpecahan elit politik yang serius, hal yang tidak kalah pentingnya adalah lingkungan internasional. Indonesia telah secara jelas mendukung perdagangan bebas sebagai anggota APEC. Krisis ekonomi tahun 1997/1998 memunculkan kembali perdebatan strategi industrialisasi, yang dalam masa transisi menguatkan posisi pribumisme. Namun, tidak ada kebijakan penting yang berhasil diputuskan pada masa ini akibat terus menerusnya tekanan massa untuk merombak total sisasisa Orde Baru (reformasi total). Berdasarkan perjanjian dengan IMF, reformasi dilakukan untuk mengurangi halangan tarif dan non-tarif serta meningkatkan ekspor. Tingkat tarif secara perlahanlahan dikurangi dari 20 persen (1994), menjadi 9,5 persen (1998) dan 7,5 persen tahun 2002 (WTO 2003).

Mencermati uraian yang dibahas sebelumnya, kebijakan industrialisme yang bernuansa liberal merupakan hasil perpaduan kekuatan pendorong dan penarik. Bagi sebagian besar penentu kebijakan, ideologi nasionalisme dan pembangunan industri nasional yang kuat tetap menjadi pedoman utama. Globalisasi dan ekonomi pasar sering disamakan dengan penjajahan gaya baru dan dipandang sebagai ancaman. Meskipun berkat integrasi dengan ekonomi internasional perekonomian tumbuh pesat tahun 1993 sampai 1997 yang mencapai rata-rata 7,5 persen, krisis yang berlangsung sesudahnya meyakinkan para penganut nasionalisme ekonomi bahwa pembangunan fondasi ekonomi (utamanya industri nasional) yang kokoh tidak bisa ditawar. Proteksionisme tetap merupakan alternatif dalam melindungi industri nasional, selain perilaku usahawan swasta dalam meminta perlindungan negara, baik untuk melindungi industri yang sedang tumbuh, industri kecil, industri nasional atau hanya karena kekhawatiran kalah dalam kompetisi. Sementara kekuatan penarik yang sulit dijinakkan adalah peluang yang dapat dimanfaatkan dengan baik oleh para eksportir dan devisa yang diraih dari ekspor non-migas. Kemapanan produk tekstil, alas kaki, kelapa sawit, kayu, karet, bubur kertas dan petrokimia di pasar internasional (ditetapkan kembali sebagai prioritas Kementerian Perindustrian tahun 2009), memberi keuntungan yang sangat besar.

Sejak tahun 2004, politik dan ekonomi yang sangat terbuka disanggah oleh institusi-institusi yang menjamin persaingan bebas, seperti media massa. Hal ini menyebabkan pemerintah memiliki mekanisme kebijakan industri yang sangat terbatas. Ditambah kompetisi antar kelompok dan partaipartai yang sangat keras, kecil kemungkinan pemerintah menetapkan agenda kebijakan industri yang mandiri dan konsisten. Dengan menekankan program yang pro growth, pro poor dan pro jobs, Kementrian Perindustian tidak bisa mengesampingkan kerangka kerja pada masa yang lalu. Dalam Rakornas Ristek tanggal 16 April 2008 di Palembang, Menteri Perindustrian menyampaikan Rancangan Penguatan Sistem Inovasi dalam Perspektif Kebijakan Industri Nasional (Fahmi Idris 2008). Kebijakan membantu industri-industri yang padat karya untuk bisa menyerap lebih banyak tenaga kerja, tetap menjadi prioritas, sedangkan dalam rangka meningkatkan pertumbuhan industri, kebijakan yang dipilih adalah pembentukan dan penguatan kelompok (kluster). Dalam tujuan dikemukakan "untuk meningkatkan penyerapan tenaga kerja, meningkatkan ekspor, meningkatkan kemampuan teknologi industri, pendalaman struktur dan diversifikasi produk", penekanan pada industri padat karya tidak mungkin dihindari. Menteri Perindustrian juga mengidentifikasi sektorsektor strategis dan terdapat 32 sektor berdasarkan kajian timnya. Luasnya cakupan ini menunjukkan kompromi politik dari pada pertimbangan ekonomi atau pemihakan ideologi industrialisme. Belajar dari pengalaman Korea Selatan dan Brasil (Neumann 2013), arah kebijakan semacam ini sesuai 
dengan distorsi birokrasi dan memfasilitasi (fostered) ketimpangan pendapatan karena membiarkan berlangsungnya ekonomi rente dan membuat institusi-institusi negara bekerja tidak efektif.

\section{Perluasan dan pendalaman}

Memperhatikan perubahan struktur perekonomian, industrialisasi di negeri ini sangat berhasil. Dalam waktu 20 tahun (1970-1990), konstribusi sektor industri terhadap pembentukan PDB dapat melampaui sektor pertanian. Peranan sektor industri manufaktur dalam perekonomian Indonesia sangat besar. Meningkatnya secara drastis sektor industri tentu membanggakan para pembuat kebijakan negeri ini karena upaya untuk melakukan modernisasi secara jelas menunjukkan hasil. Namun, kemajuan yang berjalan tidak ditopang oleh struktur yang memadai, baik struktur dalam arti kelembagaan beserta aturan yang terbuka dan adil maupun tahapan dalam transformasi. Menghadapi krisis keuangan Asia, ekonomi Indonesia jatuh yang kemudian menyebabkan krisis multidimensi. Sektor industri manufaktur mengalami konstraksi sebesar minus 11,4 persen tahun 1998, padahal tahun 1996 tumbuh 12 persen. Negeri ini memerlukan waktu lebih lama untuk melakukan pemulihan dibanding Korea Selatan, Thailand, dan Malaysia yang memperlihatkan betapa lemahnya kelembagaan. Revitalisasi, konsolidasi dan restrukturisasi merupakan fokus kebijakan industri pasca krisis 1997/1998, selain pengembangan industri kompetitif dengan pendekatan kluster (Deperin 2005).

Persoalan penting dalam industrialisasi di negeri ini, sebagaimana dikemukakan oleh Arif dan Hill (1985), Bank Dunia (1993), Wie (1994), Firdausy (2006), Kuncoro (2007, 2010) dan Tambunan (2010), adalah lemahnya hubungan antar industri atau struktur industri. Pembangunan industri suatu negara lazimnya bukan hanya memperhatikan perluasan atau diversifikasi (struktur horizontal), yang tidak kalah penting dalam menyangga perekonomian adalah pendalaman (struktur vertikal). Membandingkan kondisi tahun 1970-an dengan tahun 2000-an, terjadi perluasan yang cukup besar pada barang-barang industri yang dihasilkan di negeri ini. Pertumbuhan industri dari makanan dan minuman, tekstil dan produk tekstil, karet, produk karet dan plastik, penerbitan dan percetakan, reproduksi media rekaman dan peralatan komunikasi, serta perlengkapannya cukup besar. Jika klasifikasi yang digunakan dua digit atau bahkan tiga digit, diversifikasinya lebih besar lagi. Seiring dengan berlangsungnya diversifikasi, jumlah perusahaan pun mengalami pertumbuhan yang pesat. Pada awal tahun 1980-an jumlah perusahaan besar dan menengah kurang dari 10 ribu, tetapi tahun 2009 telah mencapai 30 ribu lebih. Diversifikasi juga memberikan indikasi kemampuan teknologi dari industri nasional (Tambunan 2010:22). Pada umumnya teknologi yang terkandung dalam barang modal lebih kompleks dari barang konsumsi. Mengikuti logika ini, maka struktur horizontal kurang memiliki kandungan teknologi yang besar.

Struktur horizontal menunjukkan keanekaragaman jenis industri baik pokok maupun turunannya. Pada masa pemulihan (recovery) yang berlangsung antara tahun 1999-2004, jumlah industri besar dan sedang tidak mengalami perubahan yang berarti. Jumlah perusahaan industri besar dan sedang selama masa pemulihan sekitar 20 ribu. Jenis industri makanan-minuman, pakaian jadi, barang galian bukan logam, mebel dan industri pengolahan lainnya, tetap mendominasi pasca krisis ekonomi. Setelah berlangsung pemulihan ekonomi, jenis-jenis industri ini mengalami pertumbuhan pesat, misalnya industri makanan dan minuman meningkat hampir dua kali lipat antara tahun 2001 sampai 2006, demikian pula tekstil dan pakaian jadi.

Struktur vertikal industri merujuk terbangunnya industri yang saling menopang dari hulu- antarasampai hilir. Salah satu metode untuk mengetahui kedalaman industri semacam ini adalah dengan menghitung rasio dari nilai input yang diimpor terhadap nilai output yang dihasilkan (Tambunan 2010:22). Menurut Kuncoro (2010) industrialisasi di Indonesia tidak menunjukkan adanya backward linkage industrialization karena ketergantungan yang sangat besar terhadap impor. Selain ketimpangan pendapatan antar golongan yang cukup tinggi, perilaku konsumtif golongan menengah ke atas, sebagai akibat melonjaknya pendapatan juga mempengaruhi kegagalan produksi barangbarang antara (intermediate goods). Dengan demikian, kegagalan proses pendalaman (deepening process) tidak semata-mata kebijakan industri yang gagal memanfaatkan "rejeki minyak" dan membaca iklim perdagangan internasional. Jika disimak ke belakang, sesungguhnya pemerintah telah 
mencegah perilaku golongan menengah dalam membelanjakan barang-barang impor dan bermuatan impor yang tinggi ini dengan mengkampanyekan "cinta produksi dalam negeri" dan pembentukan Menteri Muda Urusan Peningkatan Penggunaan Produksi Dalam Negeri, tetapi tidak segera muncul barang jadi yang memenuhi kebutuhan golongan menengah, seperti mobil dan barang-barang elektronik lainnya. Kondisi ini masih berlangsung hingga tahun 2011, yang dapat ditemukan pada data empiris bahwa industri hilir di Indonesia sebenarnya perakitan dari produk-produk merk luar negeri (Tambunan 2010:22).

\section{Kontinyuitas konflik industrial}

Deskripsi kebijakan industri yang cenderung melebar dan kurang mendalam, mempunyai hubungan logis dengan kontinyuitas konflik industrial di negeri ini. Dilihat dari kebijakan industri, terdapat tiga jenis konflik industrial. Pertama, konflik normatif yang berlangsung antara 1990-1997/1998, disebut konflik normatif karena yang diperjuangkan oleh pekerja hanyalah dipatuhinya ketentuan normatif, seperti pembayaran upah sesuai dengan ketentuan upah minimum, pembayaran tunjangan hari raya, diberikannya ijin cuti melahirkan dan diijinkannya mendirikan serikat pekerja. Tidak adanya peluang politik (political opportunity) dibawah kendali keamanan yang sangat ketat serta trauma gerakan buruh akhir tahun 1960-an, menyebabkan tuntutan hanya bersifat normatif. Meskipun demikian, tuntutan semacam ini merupakan strategi jitu. Para pekerja merasa beresiko berhadapan langsung dengan pemerintah. Trauma peristiwa 1965/1966 masih kuat melekat dalam pikiran para aktivis pekerja, begitu muncul tuntutan terhadap pemerintah akan dihadapi dengan kekerasan dan stigma komunis. Siapapun tahu bahwa stigma semacam ini mematikan, sampai kepada anak cucunya. Demikian pula berhadapan langsung dengan pengusaha tidak kalah berisiko. Pemutusan hubungan kerja dengan berbagai alasan, mulai disiplin kerja sampai kriminalisasi, menanti para aktivis atau mereka yang diduga sebagai pemimpin. Terlebih-lebih dalam sistem kapitalisme rente dimana para birokrat sipil maupun militer bertindak sebagai pemburu rente dan pelindung para pengusaha, protes pekerja jelas menjadi musuh bersama mereka. Demi menjaga "stabilitas nasional", polisi dan militer akan menghadapi pemogokan ataupun protes para pekerja.

Pilihan melakukan tuntutan normatif memiliki dasar argumen yang kuat, dimana pekerja menuntut hak yang diberikan oleh pemerintah dan dilanggar oleh pengusaha. Dengan demikian, perjuangan para pekerja bukan gerakan melawan pemerintah atau menyingkirkan pengusaha, seperti yang dianut oleh Gerakan Buruh Internasional I dan II atau oleh Partai Komunis, seperti yang dilabelkan kepada para buruh, melainkan perjuangan untuk menegakkan kewibawaan pemerintah agar keputusannya (baik SK Menaker maupun SK Gubernur) dipatuhi pengusaha. Meskipun demikian, penangkapan para aktivis pekerja terus berlangsung dan kekerasan sistematis dilakukan oleh polisi dan militer. Hingga akhir tahun 1990-an, para pekerja adalah segmen masyarakat yang paling aktif memperjuangkan hakhaknya. Jasa besar kelompok ini dalam demokratisasi adalah posisinya sebagai perintis dan pembuka ruang, yang diikuti golongan terdidik sehingga menjadi gerakan besar yang menumbangkan pemerintah Orde Baru. Oleh karenanya tidak tepat simpulan Tornquist (2003:81) bahwa buruh hanya memainkan peran tidak langsung dalam kelahiran negara demokrasi pasca Orba.

Konflik normatif semacam ini muncul dan berkembang pada fase intensitas pembentukan kekuatan pekerja, yaitu dengan ditempuhnya industrialisasi berorientasi ekspor. Peralihan dari kebijakan pribumisme ke industrialisme segera diikuti pembentukan angkatan kerja murah yang sangat massif. Tenaga kerja sektor industri pada tahun 1972 masih 7,8 persen dari total tenaga kerja, tahun 1990 menjadi 11,2 persen, dan pada tahun 2009 telah mencapai 27,3 persen atau 28,9 juta. Sejak akhir tahun 1980-an, sektor industri produk pangan, minuman, tembakau, produk kayu dan tekstil paling besar menyerap tenaga kerja. Keempat sektor industri ini mempekerjakan antara 45-50 persen jumlah tenaga kerja. Jika dimasukkan industri ringan lainnya, seperti mebel, percetakan dan penerbitan, produk karet dan plastik, pekerja yang bekerja di sektor ini mencapai 77-82 persen dari seluruh pekerja (BPS-Statistik Industri Besar dan Sedang 1986, 1990, 1995). Dilihat dari latar belakang sosial, pekerja angkatan 1980-an lebih terdidik hasil dari perluasan kebijakan pendidikan dasar dan menengah di pedesaan tahun 1970-an. Tidak mengherankan jika mereka lebih kritis terhadap situasi 
sosial. Anak-anak yang lahir pada awal Orde Baru ini mengkonsumsi konsep-konsep modernisasi melalui mata pelajaran Pendidikan Moral Pancasila dan Ilmu Pengetahuan Sosial. Mobilitas geografis desa-kota yang mereka lakukan jelas disertai harapan meningkat untuk melakukan mobilitas sosial. Dibentuk oleh lingkungan pabrik yang memasok isu-isu sosial dan kesejahteraan dan kenyataan akan berlangsungnya pelanggaran hak-hak pekerja, maka konflik normatif merupakan pilihan rasional dilihat dari lingkungan politik saat itu.

Kedua, konflik substantif, disebut konflik substantif karena muatan konflik industrial pada tahun 1999-2004 riil kepentingan para pekerja, birokrat pemburu rente dan pengusaha. Konflik substantif mengungkapkan dengan jelas kepentingan-kepentingan para pelaku, seperti tuntutan membongkar undang-undang ketenagakerjaan, kebebasan membentuk serikat pekerja dan pembayaran upah buruh sesuai produktivitas kerja. Pekerja dan pengusaha secara langsung berhadapan, demikian pula dengan pemerintah. Peta konflik berubah, dimana para pekerja memperkuat diri dengan membangun serikat, memanfaatkan kebebasan berserikat sebagai salah satu buah reformasi. Sementara pengusaha menawarkan diterapkannya mekanisme pasar dalam pengupahan agar lebih rasional, baik dari sisi produktivitas pekerja maupun penawaran tenaga kerja. Pemerintah tidak memperlihatkan sikap tegas dalam menyikapi situasi tersebut sebab pemerintah mengalami krisis legitimasi. Setelah legitimasi politik berhasil diraih melalui Pemilu 1999, produk hukum yang dinilai pekerja menguntungkan pengusaha dan memperkuat relasi pengusaha dengan pemerintah, dituntut untuk dicabut. Protes pekerja sepanjang tahun 1999-2000 berhasil menggagalkan diundangkannya UU No. 25 Tahun 1997 tentang Pokok-Pokok Ketenagakerjaan. Undang-undang ini disiapkan oleh Menaker Abdul Latif yang menunggalkan semua aturan ketenagakerjaan. Pemerintah dan DPR telah sepakat isi rancangan undang-undang, bahkan Presiden telah menandatanganinya. UU ini menimbulkan kecaman dan tantangan dari para aktivis pekerja karena merupakan bentuk baru pengendalian pekerja. Hal ini dapat disimak, dimana pemogokan hanya diizinkan dalam areal perusahaan, setelah mendapat izin dari pemerintah dan majikan. Selain itu, para pekerja yang terlibat pemogokan tidak berhak mendapat upah. Tuntutan para aktivis untuk memberikan kebebasan berserikat, tidak diakomodasi dalam UU tersebut. Penolakan mulai dilancarkan para pekerja ketika kekuasaan Soeharto telah melemah dengan berlangsungnya pertarungan elit, tetapi krisis ekonomi dan mudahnya ketetentuan PHK, menakutkan para buruh untuk bergerak menolak UU tersebut. Aksi penolakan mendorong Presiden Abdurrahman Wahid mengeluarkan Perpu No. 3 Tahun 2000 tentang Perubahan atas UU No. 1/1998, tentang Perubahan Berlakunya UU No. 25/1997. Perpu tersebut menetapkan berlakunya UU No. 25 Tahun 1997 mulai 1 Oktober 2002.

Konflik substantif juga dapat disimak dari keberhasilan para pekerja memaksa pemerintah membekukan SK Menaker 06/Men/1998 tentang Upah Minimum. Upah minimum di Jakarta berdasarkan SK tersebut sebesar Rp 198.500 setara dengan US\$ 14,10 sebulan. KUM (Ketentuan Upah Minimum) tersebut ditolak para pekerja melalui demonstrasi besar-besaran yang melumpuhkan Jakarta, Tangerang, dan Bekasi pada 1 Juli 1998, yang untuk pertama kalinya diperingati Hari Buruh setelah tahun 1965. Strategi yang oleh Juliawan (2011) disebut street level politics ini cukup efektif mempengaruhi pengambil keputusan. Para pekerja mendapat KUM baru naik 15 persen dari yang lama, dibawah Menteri Tenaga Kerja Fahmi Idris. Namun, tuntutan para buruh terus meningkat karena KUM baru hanya mencapai 95 persen Kebutuhan Fisik Minimum (KFM). Padahal KFM masih menempatkan pekerja di bawah garis kemiskinan. Tuntutan buruh dapat dipahami mengingat upah merupakan satu-satunya pendapatan bagi mereka. Studi Umar (2012) menunjukkan bahwa peningkatan upah berpengaruh positif terhadap kinerja dan motivasi kerja. Ini berarti para buruh telah memberikan sumberdaya yang memadai untuk peningkatan produksi, sehingga tuntutan kenaikan upah logis mereka lakukan. Di bawah kepemimpinan SBSI dan PPBI, gerakan pekerja menuntut kenaikan upah sebesar Rp 500.000 per bulan. Jakarta dan kota-kota industri lainnya hampir lumpuh oleh demonstrasi para pekerja yang berlangsung hampir setiap hari. Menaker mengambil jalan tengah dengan melibatkan Pemerintah Daerah dalam menentukan upah dan perubahan komposisi Dewan Pengupahan baik di Pusat maupun Daerah.

Para pekerja juga berhasil memaksa Menteri Tenaga Kerja untuk mencabut Kepmenaker No. 78/2001, yang semula dimaksudkan untuk menggantikan Kepmenaker No. 150/2000 tentang Penyelesaian 
Pemutusan Hubungan Kerja dan Penetapan Uang Pesangon. Kepmenaker 150/2000 mewajibkan pengusaha memberikan pesangon dan penghargaan bagi pekerja yang mengundurkan diri, termasuk pekerja yang melanggar peraturan. Ketentuan ini ditolak oleh pengusaha sebab sangat memberatkan dan melanggar asas kepantasan, dimana pelanggar aturan (kriminal) mendapat pesangon. Sementara para aktivis buruh berusaha membentengi ketentuan tersebut dengan memasukkannya dalam RUU Ketenagakerjaan. Para investor menilai bahwa ketidakpastian peraturan ketenagakerjaan menjadi salah satu hambatan mereka berinvestasi di Indonesia. Osamu Watanabe Chairman and CEO JETRO mengeluhkan dua persoalan penting investasi, yaitu perizinan dan ketidakpastian aturan ketenagekerjaan (Kompas 24 Oktober 2005). Berbagai lobi dilakukan oleh para pengurus APINDO dan KADIN untuk kembali ke Kepmenaker 78/2001, tetapi kalah oleh demonstrasi pekerja yang mengepung kota-kota industri pada Juni-Juli tahun 2001.

Konflik industrial yang tidak kalah masif adalah penyusunan RUU oleh Serikat Pekerja.Setelah UU No. 25/1997 dinyatakan ditunda pemberlakuannya, pemerintah mengundangkan kembali UU No. 22/1957 dan UU No. 12/1964 untuk mengisi kekosongan hukum. Namun, perlunya reformasi hukum ketenagakerjaan mendorong serikat-serikat pekerja menyusun RUU Ketenagakerjaan dan RUU Penyelesaian Perselisihan Hubungan Industrial (PPHI). Sebanyak 22 serikat pekerja yang tergabung dalam Komite Anti Penindasan Buruh (KAPB) membuat draf RUU dan menolak draf yang diajukan oleh pemerintah kepada DPR, sebab menilai bahwa RUU pemerintah berpihak ke pengusaha, terutama ketentuan mengenai outsourcing, perjanjian kerja waktu tertentu, pengupahan, uang pesangon dan penyusunan Perjanjian Kerja Bersama (PKB). Dalam draf pemerintah, butir-butir tersebut sengaja melemahkan pekerja dengan maksud menarik investasi sebanyak mungkin. Sebaliknya dalam draf yang disusun serikat pekerja, posisi pekerja diperkuat dalam butir-butir tersebut, sehingga pengusaha sangat sulit melakukan PHK. Draf yang diajukan serikat pekerja menunjukkan bahwa keamanan kerja, kepastian pengupahan, perlindungan pekerja yang menjadi anggota serikat pekerja dan kebebasan pekerja menyuarakan kepentingannya lebih diutamakan.

Peristiwa yang tidak kalah serius adalah keberhasilan gerakan pekerja menggagalkan amandemen Undang-undang No. 13 tahun 2003. Undang-undang ini, sejak penyusunannya tahun 2002, terus menerus diprotes para pekerja. Komite Anti Penindasn Buruh (KPAB) yang beranggotakan 22 serikat pekerja tingkat nasional, antara lain FNPBI, KASBI dan SBJ, menolak RUU Ketenagakerjaan karena RUU tersebut semakin membatasi hak mogok kerja, melegalkan pekerja outsourcing, dan mengizinkan penerapan kontrak kerja waktu tertentu (KKWT). RUU Ketenagakerjaan dinilai oleh para pengamat hukum perburuhan berpihak ke investor. Rita Olivia dan Surja Tjandra dari LBH Jakarta menyatakan bahwa terdapat 56 pasal yang kontroversal dan melemahkan pekerja, seperti pembatasan mogok, penutupan perusahaan (lock out), pengaturan pemborongan pekerjaan (outsourcing), kerja lembur, perjanjian kerja waktu tertentu dan upah selama mogok kerja (Tabloid Kontan 2 September 2002). RUU tersebut akhirnya disetujui DPR dan diundangkan menjadi UU No. 13 Tahun 2003, meskipun ribuan buruh berdemonstrasi selama dua hari di Jakarta dan menduduki gedung DPR dan Kantor Depnakertrans. Masalahnya, Menaker mendapat dukungan dari empat serikat buruh besar, yaitu KSPSI, KSBSI, SPSI Reformasi dan KSPI. Menaker Jacob Nuwa Wea justru menyebut para demonstran sebagai "itu bukan buruh, tetapi orang-orang di pinggir jalan yang diupah untuk berdemonstrasi” (Tabloid Kontan 2 Februari 2002).

Pemerintah pada awal tahun 2006 berencana merevisi UU Ketenagakerjaan tersebut. Revisi ini diperlukan sebab menurut Menakertrans Erman Suparno, UU tersebut sangat memberatkan pengusaha, menakutkan para investor dan tidak memberi peluang penciptaan lapangan kerja. UU hanya berpihak kepada pekerja formal dan kurang memfasilitasi para pencari kerja (Kompas 17 Maret 2006). Rancangan revisi yang mencakup 21 butir, antara lain penghilangan perlindungan negara bagi pekerja dengan mewajibkan pemberi kerja memberi perlindungan mencakup kesejahteraan, keselamatan dan kesehatan mental maupun fisik. Pekerja asing juga tidak dibatasi untuk menduduki jabatan tertentu dalam perusahaan. Selain itu, outsourcing akan diijinkan untuk semua jenis pekerjaan dan masa kontraknya diperpanjang dari dua tahun menjadi lima tahun. Pekerja dapat dipecat karena ikut mogok yang tidak disetujui pengusaha. Merespon rancangan revisi ini, serikat pekerja lokal 
Tangerang membentuk Afiliasi Kongres Serikat Pekerja Indonesia (AKSPI) dan mengepung gedung DPR dan Kantor Menakertrans selama tiga hari penuh. Berbeda dengan tahun 2003, pada tahun 2006 ini KSPI terpecah, dimana SPN dan FSPMI menolak revisi. FNBPI dengan keras menolak revisi, bahkan menuntut UU tersebut dicabut dan diganti yang baru. Sementara SBSI dan KSPSI mendukung rencana pemerintah merevisi UU tersebut.

Di daerah-daerah, pemerintah mendukung pekerja seperti di Batam, Surabaya, Makasar, Medan dan Bandung. Pemerintah daerah kawatir, revisi akan meminggirkan pekerja lokal yang semakin sulit mendapatkan pekerjaan (Koran Tempo 6 April 2006). Di Lampung dan Pangkal Pinang, para pekerja sepakat memboikot pemilihan kepala daerah jika revisi dilanjutkan (Kompas 6 April 2006). Revisi dinilai oleh para aktivis pekerja sebagai desakan kapitalis internasional untuk semakin leluasa menguasai perekonomian Indonesia. Sementara Indonesia hanya berkesempatan menjadi pekerja kontrak, nyaris seperti perbudakan modern. Presiden SBY akhirnya meminta para pekerja mengabaikan draf revisi dan berjanji akan mendengar aspirasi para pekerja. "Tidak mungkin negara atau pemerintah membuat undang-undang yang menyengsarakan rakyat. Persepsi semacam itu keliru" (Kompas 9 April 2006).

Ketiga, konflik politik. Berbeda dengan konflik industrial yang berlangsung di negara maju, dimana para pekerja yang melahirkan partai sosial demokrat mendukung ideologi pekerja, seperti pembayaran pajak pendapatan, pajak tinggi untuk barang-barang modal yang mengancam kelangsungan pekerja, jaminan sosial yang kuat dan hak-hak pekerja yang terjamin; ideologi pekerja di Indonesia terfragmentasi (Rochadi 2009, 2010). Sebagai kelanjutannya, konflik industrial senantiasa bermuatan politik. Pekerja gagal membangun partai politik sebagai sarana komunikasi dan agregasi kepentingan karena warisan sejarah. Pada masa Orde Lama, serikat pekerja membangun jaringan organisasi dengan partai-partai politik (onderbouw) dan dihentikan oleh pemerintah Orde Baru melalui kebijakan massa mengambang. Pasca Orde Baru tumbuh ratusan partai politik dan serikat pekerja. Keduanya berusaha saling mempengaruhi dan membangun ketergantungan. Ada partai politik yang mendekati dan meminta dukungan serikat pekerja dengan menjanjikan jabatan politik kepada ketua serikat seperti yang terjadi pada PDIP dan Kesatuan Buruh Marhaen (KBM), Partai Daulat Rakyat dengan Gaspermindo, PPP dengan SPSI Reformasi, ada pula serikat pekerja yang mendekati partai menawarkan dukungan dan meminta imbalan kebijakan upah yang pro buruh, seperti PKS dengan Serikat Pekerja Nasional (SPN) dan Serikat Pekerja Metal Indonesia (SPMI). Pola yang tidak kalah menjamurnya adalah partai-partai membentuk serikat pekerja sebagai organisasi sayap, seperti PKB dengan Sarbumusi, Golkar dengan KSPSI. Partai Buruh yang dibangun oleh SBSI gagal meraih kursi baik pada pemilu 1999 maupun 2004. Dengan pola semacam ini, para pekerja terseret dalam konflik politik partai-partai dan saling berhadapan yang melemahkan kekuatan para pekerja.

Kontinyuitas konflik industrial seperti yang dikemukakan di atas miskin isu-isu lapangan pekerjaan, seperti peningkatan kualitas pekerjaan, peningkatan kualitas SDM, alih teknologi, pendidikan dan pelatihan pekerja, penguasaan teknologi guna menghadapi kompetisi dan sebagainya. Isu-isunya terus menerus masalah upah, status pekerja, pembayaran THR, dan riuh rendah mendukung partai politik, atau calon kepala daerah dan calon presiden. Kebijakan industrialisasi dalam kaitannya dengan pekerja seakan hanya dipahami peningkatan jumlah tenaga kerja dan konstribusinya dalam perekonomian nasional. Kebijakan industri yang kuat yang ditandai dengan pendalaman industri dan ditunjukkan melalui keterkaitan vertikal, merupakan landasan kokoh dalam pembangunan industri. Kebijakan demikian juga mengarahkan pengorganisasian pekerja cenderung berdasarkan lapangan kerja, sehingga isu-isu pekerjaan yang lebih berbobot profesional akan lebih mengemuka.

\section{Simpulan}

Pada era Orde Baru, dimana pemerintah sangat kuat, yang ditunjukkan oleh penguasaan modal dan kebebasan menentukan kebijakan, ideologi nasionalisme menjadi acuan penentu kebijakan industri. Baik nasionalisme ke dalam (pribumisme) maupun nasionalisme yang diorientasikan ke luar (industrialisme), sama-sama merindukan terbangunnya struktur industri yang kuat. Kegagalan 
memanfaatkan uang yang melimpah dari rezeki minyak bumi dan kebijakan industri yang tidak fokus, akibat terlalu mengakomodasi kepentingan berbagai kelompok (birokrat pemburu rente, pedagang, pengusaha yang mendompleng negara), hanya menghasilkan struktur industri yang luas. Struktur demikian memang memberi konstribusi dalam perekonomian nasional, yaitu terciptanya lapangan kerja, terjaganya pertumbuhan ekonomi dan yang paling penting pada saat itu pengurangan perekonomian nasional dari ketergantungannya kepada minyak bumi. Namun demikian struktur industri yang luas tanpa didasarkan kepada industri hulu yang kuat hanya menjadikan pekerja sebagai perakit atau penjahit.

Struktur industri yang luas juga mengabaikan kualitas sumber daya manusia. Pada industri ringan, pekerja dengan latar belakang jenjang pendidikan apapun mengerjakan pekerjaan yang sama dengan upah yang sama dan nyaris tanpa karier. Perubahan upah pekerja jenis ini hanya berdasarkan keputusan pemerintah tentang Upah Minimum Provinsi atau Kota yang ditetapkan oleh kepala daerah setiap tahun. Selain menyebabkan kemubaziran sumber daya manusia, gejala semacam itu menyediakan lahan subur bagi konflik pekerja. Inti persoalannya adalah tidak terbangunnya struktur industri vertikal yang kuat sehingga pekerja terkonsentrasi di industri hilir, yang sebagian besar tidak memerlukan keterampilan. Mata rantai berikutnya adalah tidak adanya perbedaan upah secara signifikan antara pekerja senior dan yunior. Hal ini disebabkan pada industri ringan tidak terdapat tangga mobilitas vertikal yang memadai. Terus meningkatnya angkatan kerja menjadi tekanan tersendiri bagi pekerja senior. Meskipun upah yang diterima hanya cukup untuk hidup sehari-hari, mereka berjuang dengan berbagai cara untuk mempertahankan pekerjaannya. Kondisi ini merupakan lingkungan yang kondusif terjadinya konflik industrial.

Konflik normatif, konflik substantif maupun konflik politik, bisa berjalan bersama-sama maupun masing-masing. Ketiga bentuk konflik yang dilihat dari muatan (content) bukanlah tahapan, tetapi klasifikasi untuk menunjukkan minimnya konflik bermuatan pengembangan sumber daya manusia dan teknologi. Konflik industrial akan mempunyai konstribusi positif bagi pengembangan SDM dan penguasaan teknologi apabila dibimbing oleh isu-isu seputar pekerjaan. Karenanya pengorganisasian pekerja perlu ditinjau ulang dengan memikirkan kembali pentingnya serikat pekerja berdasarkan lapangan industri, sehingga memandang serikat sebagai sumber daya yang tentunya akan merugikan semua pekerja jika serikat mengalami perpecahan. Selain itu, kebijakan industri perlu lebih diarahkan pada penguatan jaringan antara industri kecil-menengah dengan industri besar. Memperkuat industri manufaktur, yang selama ini terbukti menyerap banyak tenaga kerja, perlu dipertahankan, tetapi peningkatan kualitas untuk menjadi industri kelas dunia yang lebih mengandalkan penguasaan teknologi mendesak dilakukan.

\section{Daftar Pustaka}

Arif M \& Hill H (1985) Export-oriented industrialization: The Asean Experience. Sydney: Allen \& Unwin.

Austin G (2010) The Developmental state and labour-intensive industrialization: 'late development' reconsidered 25 (1):51-74.

Bank Dunia (1993) Industrial policy-shifting into high gear. Washington DC: World Bank.

BPS (1986) Statistik industri besar dan sedang. Jakarta: BPS.

BPS (1990) Statistik industri besar dan sedang. Jakarta: BPS.

BPS (1995) Statistik industri besar dan sedang. Jakarta: BPS.

Budiman A (1994) Negara dan pembangunan: pengalaman Indonesia dan Korea Selatan. Jakarta: Yayasan Padi dan Kapas.

Chalmers I (1996) Konglomerasi: negara dan modal dalam industri otomotif Indonesia. Jakarta: Gramedia.

Crouch H (1979) Patrimonialism and military rule in Indonesia. World Politics 31(4):571-587. 
Doner R (1998) Politik dan pertumbuhan modal lokal di Asia Tenggara: industri mobil di Filipina dan Thailand. Dalam: McVey R (ed). Kaum kapitalis Asia Tenggara. Jakarta: Yayasan Obor Indonesia, p.334-388.

Feith H \& Castle L (ed) (1988) Pemikiran politik Indonesia. Jakarta: LP3ES.

Firdausy CM (2006) Dinamika pembangunan industri manufaktur dalam era globalisasi. Dalam: Firdausy CM (ed). Kebijakan pembangunan ekonomi Indonesia dalam era globalisasi di sektor industri manufaktur. Jakarta: LIPI, p.29-74.

Fukuyama F (1992) The end of history and the lastman. New York: Penguin Book.

Hadiz VR (1997) Workers and the state in new order Indonesia. New York: Routledge.

Idris F (2008) Rancangan penguatan sistem inovasi dalam perspektif kebijakan industri nasional. Jakarta: Kementrian Perindustrian.

Irwan A (1999) Jejak-jejak krisis di Asia ekonomi politik industrialisasi. Yogyakarta: Kanisius.

Juliawan BH (2011) Street-level politics: labour protests in post-authoritarian Indonesia. Journal of Contemporary Asia 41 (3):349-370.

Kim C (2005) An industrial development strategy for Indonesia: Lessons from the South Korea experience. Journal of the Asia Pacific Economy 10 (3):312-338.

Kompas (2005) Aksi buruh rusak iklim berusaha. Kompas, 24 Oktober 2005, p.17.

Kompas (2006) Menaker: Revisi mendesak. Kompas, 17 Maret 2006, p.18.

Kompas (2006) Buruh ancam boikot Pilkada. Kompas, 6 April 2006, p.21.

Kompas (2006) Presiden: Abaikan draf revisi UU 13/2003. Kompas, 9 April 2006, p.17.

Koran Tempo (2006) Pemerintah daerah dukung buruh. Koran Tempo, 6 April 2006, p.3.

Kuncoro M (2007) Ekonomika industri Indonesia: Menuju negara industri baru. Yogyakarta: Penerbit Andi.

Kuncoro M (2010) Masalah, kebijakan dan politik ekonomika pembangunan. Jakarta: Erlangga.

Majchrcak A (1984) Methods for policy research. London: Sage.

Nasir M (2001) Metode penelitian. Jakarta: Ghalia Indonesia.

Neuman WL (2013) Social research methods: qualitative and quantitative approaches, 7th edition. Boston: Allin and Bacon.

Neumann S (2013) Import subtitution industrialization and its conditionalities for economic development- a comparative analysis of Brazil and South Korea. Departement of International Relation and European Studies- Central European University, Budapest.

Nugroho R (2013) Metode penelitian kebijakan. Yogyakarta: Pustaka Pelajar.

Partawidjaja D, Yusron UN, dan Turisman T (2002) Nuwa Wea: Yang menolak bukan buruh. Tabloid Kontan, 2 September 2002, p.1.

Rasiah R and Hing Ai Yun (2009) Industrializing South East Asia. Journal of the Asia Pasific Economy 14 (2):107-115.

Rochadi S (2009) Kepemimpinan dalam gerakan buruh di Indonesia pasca orde baru. Majalah Nation 6(2): 55-73.

Rochadi S (2010) Taksonomi gerakan buruh di Indonesia pasca orde baru. Majalah Ilmu dan Budaya 31(22): 2309-2328.

Selwyn B (2011) Trotsky, gerschenkorn and the political economy of the late capitalist development. Economy and Society 40 (3):421-450.

Sjahrir (1993) Refleksi Pembangunan Ekonomi Indonesia 1968-1992. Jakarta: Gramedia.

Soehoed AR (1988) Reflection on industrialisation and industrial policy in Indonesia. Bulletin of Indonesian Economic Studies 24: 41-53.

Sumartomdjam M dan Yusron UN(2002) 56 Pasal Bermasalah. Tabloid Kontan, 2 Februari 2002, p.1.

Tambunan TTH (2001) Industrialisasi di Negara Sedang Berkembang Kasus Indonesia. Jakarta: Ghalia Indonesia.

Tambunan TTH (2010) Perkembangan industri nasional dan peran PMA. Jurnal Ekonomi dan Pembangunan XVIII (1): 21-36.

Tornquist O (2003) Buruh dan demokrasi? Refleksi tentang kebuntuan politik di Indonesia. Dalam: Priyono AE, Prasetyo SA \& Tornquist O (eds.) Gerakan Demokrasi di Indonesia PascaSoeharto. Jakarta: Demos, ISAI dan SAREC, p.73-90.

Umar A (2012) Upah meningkatkan kinerja dan motivasi kerja para pekerja di industri manufaktur di Kota Makasar. Jurnal Masyarakat, Kebudayaan dan Politik, Vol. 25 (1) p.78-85. 
Vrendenbregt J (1980) Metode dan teknik penelitian masyarakat. Jakarta: Gramedia.

Wade R (1992) Peran pemerintah dalam menanggulangi kegagalan pasar: Taiwan, Korea Selatan dan Jepang. Dalam: Hughes H (ed). Keberhasilan Industrialisasi di Asia Timur. Jakarta: Gramedia, p.176-227.

Wie TK (1994) Industrialisasi di Indonesia beberapa kajian. Jakarta: LP3ES.

WTO (2003) Trade policy review: Indonesia 2003. Geneva: WTO. 